\title{
ПРОЕКТ «РУССКАЯ ЛИВОНИЯ»
}

\section{THE “RUSSIAN LIVONIA” PROJECT}

The 'Russian Livonia' project was an attempt to establish a province of Russian Tsardom in the lands conquered in Livonia between 1558-1560 which could be regarded as a model of integration of foreign territories into Russia in the $16^{\text {th }}$ century. Russian authorities used a number of integration approaches, such as the system of agreements with Livonian cities and later the political model of the Holy Roman Empire. They tried to found a Livonian Kingdom, which was subordinate to Ivan the Terrible as Emperor. There were two attempts to carry out this reform: in 1564 and in 1569-1578, both unsuccessful. They never led to the integration of Livonia into the Russian state and commonwealth. The Russification of Livonia failed. Livonia saved its status as middle earth between different cultures.

Ke y w ord s: Ivan the Terrible; Livonia; Livonian War; Duke Magnus.

Проект «Русская Ливония» был попыткой создания провинции Российского царства на землях, завоеванных в Ливонии в 1558-1560 гг. Его можно рассматривать как пример модели интеграции в XVI в. Россией иноземных территорий в состав своего государства. Российские власти пробовали разные варианты этой модели: систему договоров с ливонскими городами, пытались адаптировать модель, применявшуюся в Священной Римской империи. Они старались учредить в Ливонии вассальное королевство, по отношению к правителю которого Иван Грозный выступал бы как император. Было две попытки такой реформы: в 1564 и 1569-1578 гг. Но все они оказались неудачными. Интеграция Ливонии в систему русской государственности не состоялась, попытки русификации провалились. Ливония сохранила свой статус «срединной земли» между различными культурами.

Ключевы е слов а: Иван Грозный; Ливония; Ливонская война; герцог Магнус.

На берегу Балтийского моря на 81 км шоссе Нарва - Таллин, возле деревни Кырккюла стоит каменный крест XVI в. В эстонской земле похоронен русский дворянин, он же «мужественный и благородный шведский рыцарь» Василий Росладин (Разладин). Он перешел на сторону шведов в 1582 г., в 1590 г. был убит в бою с русскими, 
и в память его был поставлен каменный крест с надписями на русском и немецком языках. Он являет собой, по выражению Анти Селарта, пример религиозного диффузионизма, поскольку содержит как протестантские, так и православные символические изображения и надписи одновременно [Селарт, 2012].

В этом русско-шведско-немецко-эстонском, православнопротестантском смешении - вся символика прибалтийской истории. Прибалтика на протяжении своего пути была на границе язычества и христианства, германского и славянского мира, Шведской и Российской империй, Евросоюза и СНГ.

Попытки преобразовать ее из «зоны срединности» в «зону идентичности» предпринимались в истории несколько раз. Немцы с помощью рыцарского ордена, католического креста и Ганзейского союза строили здесь провинцию Священной Римской империи, пока последние северные крестоносцы не полегли под русскими саблями в августе 1560 г. под крепостью Эрмес.

Именно в Прибалтике пыталась в XVI в. вступить на державный и экспансионистский путь Польша, низложив Немецкий орден и создав на основе его бывших владений в дополнение к вошедшей в состав Польши Королевской Пруссии (1466) две вассальных провинции в Прибалтике - Герцогство Пруссия (Prusy Książęce, Ducatus Prussiae, 1525) и польских Инфлянтов (с 1566 - Задвинское герцогство, Księstwo Inflanckie). Но крест на идее Польской Прибалтики поставили шведы, в первой половине XVII в. вытеснившие поляков из региона и в 1655 г. устроившие знаменитый «Шведский Потоп» уже на собственных землях Речи Посполитой.

Русский имперский проект Прибалтики XVIII-XIX вв., равно как и советская модель братских Эстонской, Латвийской и Литовской ССР хорошо известны. Однако они также не привели к созданию устойчивой к испытаниям временем имперской или советской прибалтийской «зоны идентичности»: в 1918 г. быстро рухнула империя, а в 1990-1991 гг. столь же стремительно ушел из истории стран Балтии СССР. Возможно, прибалтийские страны и народы сумеют преодолеть собственную «срединность» путем построения современных национальных государств, во всяком случае, они прилагают к этому много усилий. Другое дело, что успешность этого пути покажет только время (предыдущая аналогичная попытка государственного нациестроительства в Прибалтике в 1918-1940 гг. продлилась менее срока исторической жизни одного поколения).

Вышеперечисленные эпизоды попыток преодоления срединности этого региона хорошо известны и исследованы. Целью же настоящей статьи является рассмотрение гораздо менее изученной истории создания в Прибалтике «Русской Ливонии» Иваном Грозным в 1558-1582 гг. Почему провалился проект «Русской Ливонии», почему за 25 лет она так и не стала русской территорией, а осталась для россиян «зоной срединности» - предмет изучения в настоящей статье. 
Общеизвестно, что история попыток русского проникновения в Прибалтику начинается задолго до Ивана Грозного. Подробный обзор фактов русского присутствия в регионе в Средневековье приводится в книге Анти Селарта и в других работах [Tvauri, 1. 215-232; Selart, 2007, S. 55-68]. Некоторые балтийские местности и племена пытались обложить данью Новгород и Псков [Назарова, 1986, с. 180182; Selart, 2007, S. 60-64]. В Ерсике (Герцике) и Кокнесе (Кокенгаузе) в начале XIII в. фиксируются князья восточнославянского происхождения, но степень их политической подчиненности древнерусскому Полоцку остается предметом дискуссий [Taube, S. 391-393; Starodubec, S. 349-350; Назарова, 1995, с. 183-187; Алексеев, с. 284-287; Selart, 2007, S. 59-65, 95-99]. По летописным известиям, один из главных городов Ливонии, Юрьев (будущий Дерпт, Тарту) был основан Ярославом Мудрым в 1030 г. [см.: ПСРЛ, т. 2, стб. 137]. Постоянное военное присутствие русских в регионе выражалось и в многочисленных походах по прибалтийским землям.

Однако после прихода в XII-XIII вв. в Прибалтику немцев русские как значимая политическая сила были вытеснены из региона. Их присутствие осталось в двух видах. Во-первых, в крупных городах (Риге, Ревеле, Дерпте) были районы, заселенные славянскими ремесленниками и купцами, с православными церковными приходами [Казакова, 1975, с. 137-141, 169, 185, 252; Казакова, 1963, с. 155]. Русский язык в средневековой Прибалтике учили, хотя, конечно, не массово, а избранно: его знание «было привилегией, которая открывала двери на Русь» [ Селарт, 2014, с. 50; см. также: Forstreuter, S. 206]. Русь была выгодным рынком сбыта и направлением торгового транзита из Европы через Ливонию, от которого зависело само существование Ливонии, т. е. русский лингвистический фактор носил чисто внешний характер, воспринимался как немаловажный, но «чужой».

Во-вторых, с XV в. важной составляющей ливонского политического дискурса стал фактор «русской угрозы». Ее реальные масштабы были куда скромнее, чем представлялось в спекуляциях ливонских ландсгерров ${ }^{1}$, но этот фон играл важную роль в выстраивании политических декораций в ходе борьбы за доминирование между епископами, орденом и городами.

B XIV-XV вв. юго-восточный Балтийский регион оформляется как «мир-экономика» (в терминологии Ф. Броделя) в виде треугольника: Ливония - Великий Новгород - Псков [Бессуднова, 2009а, с. 10-55; Бессуднова, 2013]. В отношениях начинает превалировать экономическая составляющая. Военные конфликты (которые, впрочем, случались довольно часто) носили локальный характер и в конечном итоге имели в виду цель добиться более выгодных условий для торговли и заключения взаимоприемлемого мира. Никогда ни Псков, ни Новгород, ни Ливония не ставили своей целью уничтожение противника

${ }^{1}$ О проблематике «русской опасности» см.: [Selart, 1998, 1. 119-127; Маазинг; Бессуднова, 2014]. 
как государства и значительную аннексию его территории. Мелкие пограничные споры держали стороны в военном и политическом тонусе, но никогда не переходили мысленные границы дозволенного.

Все рухнуло в конце XV в. Присоединение Россией Великого Новгорода в 1471-1478 гг. разрушило одну из сторон треугольного «мираэкономики». Состав русских купцов, торговавших с Ливонией, изменился даже физически: вместо высланных новгородцев на СевероЗапад Руси приехали москвичи. У них был совсем другой стиль ведения дел: агрессивный, напористый, силовой ${ }^{2}$. Причем теперь экономика с легкостью приносилась в жертву политике. Примером может служить внезапный разгон в Новгороде немецкого Ганзейского двора в 1494 г. По предположению ряда исследователей, он был местью Ивана III за неудачи в дипломатических отношениях со Священной Римской империей [Казакова, 1963; Коваленко, Смирнов, с. 134; Бессуднова, 2009б]. Сама империя вряд ли сильно ощутила разгром одного из многочисленных региональных ганзейских дворов, но для Ивана III это был важный символический жест.

С утратой независимости Пскова в 1509-1510 гг. и его присоединением к Московскому государству «мир-экономика» в Прибалтике окончательно перестал существовать. Возникла принципиально новая геополитическая конфигурация. Возник «ливонский вопрос» [Kirchner, p. 5-33], соседние страны стали строить планы раздела Ливонии как страны, «отжившей свое».

Изменение геополитической ситуации в Ливонии совпало с политической трансформацией «Государства всея Руси». В XVI в. в своем территориальном росте Московское государство исчерпало территориальные пределы бывшей Северо-Восточной и СевероЗападной Руси и начало занимать земли, никогда раннее не входившие в состав Руси/России. В силу инерции политического мышления для этого использовался вотчинный дискурс. Захваченные земли объявлялись исконно русскими, древней вотчиной московских государей. При Иване Грозном его применяли при аннексии Казанского и Астраханского ханств и на первом этапе борьбы за Ливонию [Филюшкин, 2004, с. 387-391].

Но вотчинный дискурс был задействован только в области идеологии. В практическом плане надо было найти механизм интеграции этих земель и место этих земель в российской системе. Задача была не из простых. Русская Ливония в этом смысле выступала пилотным проектом будущей Российской империи на западном направлении проекте неудачном, несбывшемся, полузабытом. Его можно изучать именно как поиск путей реализации имперской модели на начальной стадии постепенного превращения России в империю, которую мы определяем как фазу «неонатальной империи» [Филюшкин, 2004]. До середины XVI в. традиционной моделью присоединения земель

\footnotetext{
2 Описание новой политики и стиля поведения московских купцов в Новгороде см.: [Казакова, 1975, с. 195-197].
} 
и их включения в состав «Государства всея Руси» была следующая. Она включала в себя:

- «перебор людишек» - переселение вглубь России местной элиты и ее замену на переселенцев из России: купцов, служилых людей;

- установление воеводской власти, подконтрольной Москве;

- распространение православия, в том числе путем массового церковного строительства; руководство церковью в регионах назначается Москвой и зависит от нее;

- налогообложение в пользу центра;

- воинская повинность (формирование местных служилых дворянских корпораций, подчиняющихся центральному правительству).

Эта модель прекрасно работала в время собирания под властью Москвы русских земель в XV-XVI вв. и даже в значительной степени при присоединении Казани (1552) и Астрахани (1556) [Keenan; Pelensky, 1967; Pritsak; Kampfer; Pelensky, 1974, p. 65-138]. В Ливонии же все это реализовать было непросто, т е. традиционная модель присоединения новых земель оказалась малоприменима.

Почему в Ливонии не сработала традиционная модель присоединения земель? Во-первых, это было связано с прифронтовым статусом территории, который не позволял превратить страну в «российский уезд» и заставлял хоть немного считаться с местным населением, добиваться его лояльности. Вся территория Ливонии так и не была завоевана, и даже те земли, которые называли «Русской Ливонией» с центром в Юрьеве (переименованном Дерпте), весь 25-летний период оставались зоной нестабильности, ареной боевых действий и т. д.

Во-вторых, «перебор людишек» также не состоялся. Дворянская элита Ливонии или погибла, или бежала, случаи перехода ливонской знати на русскую сторону есть, но немногочисленны [Опарина; Скобелкин]. Можно говорить о персонах, но не о социальном слое, перешедшем служить Москве.

В-третьих, массовых переселений из России в Ливонию также не было - в крепостях стояли гарнизоны, в Нарве увеличилось количество русских купцов, но не более того. Производились поместные раздачи земель [Новицкий; Angermann, S. 47-53; Флоря; Selart, 2002; Пиотух; Martin], но об их масштабе трудно судить. В любом случае, русские помещики мало жили в своих имениях, а в основном воевали на фронте, т. е. их присутствие чувствовалось преимущественно во взимании податей. Привнесения русской землевладельческой культуры на ливонскую землю не состоялось. Показательно, что русские помещики, которые не захотели бросать свои владения и возвращаться в Россию во время эвакуации 1582 г., не образовали своей, «русской корпорации», а стремительно интегрировались в местную среду, подстроились под нее, как уже упоминавшиеся Росладины. Они не хотели считаться русскими.

В 1581 г. ракверские и падисские дворяне русского происхождения участвовали в нападении шведов на российский гарнизон в Нарве, 
т. к. хотели сохранить в Ливонии свои поместья. В 1584 г. шведский король Юхан III велел «...давать [русским] “боярам” земли в Швеции, Финляндии, Кексгольмском лене, Эстляндии и Ингерманландии. В Эстонии русским были вначале пожалованы села на острове Хийумаа. В 1589 г. земли на Хийумаа, взятые обратно для государства, были заменены владениями в других местах Эстляндии и Ингерманландии. Когда Ингерманландия в 1590 г. отошла к России, в Эстляндии был, соответственно, увеличен объем «боярских» земель. В 1594 г. землевладения русских и татар в Эстонии грамотой закрепил король Сигизмунд III Ваза. В начале XVII в. русским дополнительно раздавались земли в Западной Финляндии» [Селарт, 2012, с. 6]. Происходила быстрая интеграция бывших русских дворян в знать Швеции. Если прибегать к более поздней, модерной терминологии, то русификации Прибалтики за 25 лет существования Русской Ливонии так и не получилось.

Следующая причина вытекала из целей войны. Одной из них был захват торговой инфраструктуры ливонских городов и ее использование в пользу России. Сама Россия не могла наладить морскую торговлю, построить свои порты, флот и т. д. - все попытки этого до захвата Ливонии были неудачны. Россия в XVI в. владела на Балтике городком Невское устье на Неве, который, видимо, использовался как мелкая торговая фактория. Как минимум трижды между 1536 и 1577 гг. предпринимались попытки строительства русской крепости в устье Наровы, выше по течению от Нарвы [Косточкин; Носов, c. 28]. Кроме того, вход в Неву со стороны Ладожского озера запирала русская крепость Орешек. Все эти пункты в XVI в. так и не выросли в центры торговли, оставшись военными сооружениями, обеспечивавшими только мелкую торговлю (да и то предположительно). Весь поток товаров из Европы продолжал идти через Нарву, Ревель и другие ливонские города.

Вместе с тем выгода от поступления морем вооружений и товаров из Европы была очевидной. Здесь стоит сделать ремарку к известному тезису о Ливонской войне как «войне за выход к Балтийскому морю»таковой она, конечно, не была, т. к. и до войны Россия владела всем южным побережьем Финского залива. Да и значимость «торгового фактора» в формировании направлений внешней политики России в XVI в. не стоит преувеличивать [Tiberg, S. 613; Филюшкин, 2001; Filiushkin, 2004]. Но владеть торговыми факториями было лучше, чем не владеть, и «Нарвское плавание» приносило прямую прибыль [Attman, p. 73-83, 116-118].

Поэтому Москве было важно сохранить ливонские торговые города как структурные единицы всей системы балтийской морской торговли. Горожан не трогали, или, по крайней мере, сначала старались не трогать. Жители Дерпта в «русский период» его истории отмечали корректный («вежливый») характер российской власти (наведение в городе порядка, борьбу с преступностью, защиту горожан), что отразилось в «Ливонской хронике» Франца Ниенштедта: 
Затем князь [Шуйский, командовавший русскими войсками, взявшими Дерпт. - А. Ф.] велел объявить, что под страхом смерти никто не смеет ничем обижать жителей города. Велел он также объявить, чтобы бюргерские люди не продавали в своих домах никаких напитков для ратных людей, в предупреждение несчастия. Всех русских ратников разместили в замке, в соборных помещениях и в оставленных жителями домах, и строго смотрели, чтобы они никого не обижали, а кто в этом провинился, того князь велел постыдным образом бить и плетьми наказывать; князь назначил также нескольких бояр со стрельцами для объездов по городу, которые ежедневно ездили кругом и забирали всех нетрезвых людей и всех, кто только неподобающе себя вел, и тотчас сажали в тюрьму. Видя это, бюргеры несколько успокоились в своем несчастии, и не боялись уже открытого нападения и насилия [Ниенштедт, с. 26].

Отношения с ливонскими бюргерами русские воеводы изначально пытались поставить на правовую основу. В нашем распоряжении есть уникальный документ - Жалованная грамота Дерпту 1558 г., которую можно сопоставить с требованиями горожан, выдвинутыми к русским воеводам после взятия крепости. Из сопоставления этих текстов наглядно видна разница политических культур и отличие целей, которые преследовали стороны.

История создания документа такова. 17 июля 1558 г. прошли переговоры жителей Дерпта с осаждающей город русской армией об условиях сдачи. Отдельно были поданы условия от епископа, магистрата и городской общины. Воевода П. И. Шуйский отправил их на утверждение в Москву. Их рассмотрели и 6 сентября выдали грамоту, содержание которой сильно отличалось от пожеланий жителей. Большинство условий в текст не попало, а то, что попало, было сильно искажено. При составлении документа Москва руководствовалась не договоренностями между Шуйским и магистратом Дерпта (на которых, собственно, и был сдан город), а российской традицией составления подобных актов, русской юридической практикой. Вместе с тем, какие-то безобидные требования горожан старались учесть. В итоге получился документ несколько противоречивого содержания.

Русские власти гарантировали свободу вероисповедания, неприкосновенность церквей (это совпадало с требованиями горожан). Однако пространный пункт требований о сохранении городского самоуправления был передан в грамоте очень кратко и абстрактно: «А в Юрьеве Ливонском быти им по своим обычаям», что давало широкий простор для толкований. При этом подтверждалось финансирование дерптской ратуши за счет земельных пожалований (но не городских налоговых сборов). Москва признавала наличие особого немецкого суда по торговым делам, но ввела в него русского стряпчего как наблюдателя. Воевода отверг просьбу магистрата апеллировать по спорным делам к Риге (как было раньше), взамен воеводская власть выступила гарантом защиты бургомистра и его «товарищей». 
Постой войск разрешался только в домах, оставленных горожанами. Разрешалось переселение русских в Дерпт и дерптцев в русские города на места поселения по согласованию с местными властями. Для дерптцев вводилась беспошлинная торговля в русских городах. Им было оставлено право эмиграции «за море» при уплате соответствующего налога на имущество. Русской стороной был внесен пункт, что немцы по вечерам и ночам должны ходить только с фонарями, освещать себя и по первому требованию объяснять патрулям, кто они и куда идут. По городу вводились многочисленные армейские посты.

Очень показательно, что из требований горожан не вошло в русский текст грамоты. В нее не было включено 20 из 34 пунктов. Не попали следующие требования: сохранить школы для юношества (п.3); право судебного поединка (суда мечом - п.7); сохранениегильдий и цехов (п. 9); сохранение гильдии «черноголовых» со всеми их правами (п. 10); свобода производства и торговли спиртными напитками для жителей Дерпта (п. 12); свобода продажи недвижимого имущества и возможность беспрепятственно покидать город в любое время со всеми деньгами, не платя никаких отчислений (п. 14, 18); свобода покидать город, оставляя имущество на хранении у друзей с возможностью вывезти его позже (п. 15); свобода возвращения в Дерпт с восстановлением всех прав горожанина (п. 16); запрет прямой торговли на территории Дерпта иностранных купцов, они могли совершать свои сделки только через магистрат (п. 20); магистрат сохраняет право суда над цехами (п. 21); ярмарки проводятся в традиционное время, инспекцию над торговлей осуществляет магистрат (п. 22); магистрат обладает правом прощения лиц, признанных виновными судом (п. 23); магистрат по-прежнему выдает въездные и выездные паспорта (п. 24); оккупационные власти не будут выселять бюргеров в Россию (п. 26); выморочное имущество, если оно не востребовано в течение года и одного дня, достается магистрату (п. 29); магистрат контролирует вступление в гильдии новых бюргеров (п. 30); сохраняется верховенство рижской юрисдикции над дерптскими законами (п. 31); лица, сделавшие в Дерпте долги, не могут быть арестованы во время их выезда в Россию, их дела могут рассматриваться только дерптским судом (п. 32); свобода вывоза из России для ливонских купцов хлеба, меди и продовольствия (п. 33) [Филюшкин, 2008].

Из сравнения принятых и исключенных пунктов четко видна разница политических / правовых культур: русская администрация включила в грамоту положения, обеспечивавшие ее власть и гарантию тех прав дерптцев, которые были ей выгодны («торгуйте для нас»). При этом как фундаментальная ценность провозглашалась свобода вероисповедания. Для немецких жителей Дерпта важно было сохранить свои ценности, свой modus vivendi, со всеми его компонентами - развитым судопроизводством, образованием, свободой передвижения и имущественных сделок и т. д. Русским эти пункты просто показались несущественными. 
Problema voluminis

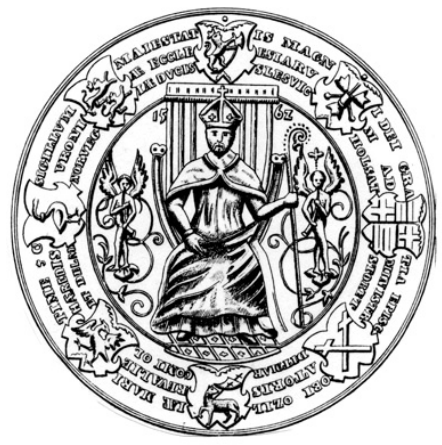

Печать Магнуса, епископа Эзельского (1560-1572), будущего «короля Русской Ливонии». Прорись

Показательно, что в грамоте нет ни слова о языке - важны религия, подданство, подчиненность судебной и местной власти, пути экономических сделок, но неважно, на каком языке говорит власть, и тем более - подданные (фактически сохранялось двуязычие воеводская власть говорила на русском, магистрат на немецком, и это не воспринималось как помеха в общении и взаимодействии). Это свидетельствует о том, что в интеграционных механизмах в XVI в. язык не рассматривался ни как фактор интеграции, ни как фактор сохранения идентичности. Конечно, это в какой-то степени было порождено принципиальным полилингвизмом

Прибалтики (многовековое сочетание латыни, немецкого и местных языков) и билингвизмом Средневековья вообще (латынь как государственный и богослужебный язык и национальные языки). Но, возможно, перед нами маркер, отделяющий неонатальную империю от империи нового времени, когда языковая политика становится фактором ассимиляции.

В любом случае, предлагаемые в жалованной грамоте Дерпту механизмы не решали проблему, как интегрировать в Россию Ивана Грозного немецкий торговый город. Видимо, сходные грамоты выдавались и другим городам (известна грамота Нарве - «Privilegium des Grossfürsten für Narva» [Schirren, S. 49-51; Renner, 1953, S. 24-25]). Сращивания в итоге не получилось, вместо него возникла атомизация населения немецких городов и стоящих в них русских гарнизонов, на которую соглашались российские власти (так было проще контролировать те же гарнизоны). В самом примитивном смысле она могла вести к имперской структуре (если трактовать империю как объединение разнородных объектов под единой властью). Но этот эксперимент оказался неудачным. С уходом России из Прибалтики немецкие города вздохнули с облегчением, а русские, по нашему мнению, не ощутили никаких последствий культурного влияния от 25-летнего стояния российских гарнизонов в Ливонии.

Свою роль сыграла и принципиальная религиозная толерантность Москвы. В Ливонии не было православного миссионерства [Selart, 2009], а отдельные акции по торжеству православия во взятых городах (крестные ходы, строительство храмов, перенос икон) имели своим адресатом русских прихожан. Католиков и протестантов не трогали, перекрещиваться не заставляли. Это не вызывало проблемы религиозного противостояния, но и не создавало почвы для интеграции на основе общей религии. 
Конечно, Ливонию не обошли проявления тирании Ивана Грозного (репрессии жителей Дерпта после подавления мятежа Таубе и Крузе 1571 г., бесчинства опричников в Нарве и т. д.). Их было не больше, чем в самой России (специально антиливонской политики мы не фиксируем, но Ливония разделяла опричный террор, обрушившийся на всю Россию). Но очевидно, что такие акции интеграции также не способствовали и подавляли саму мысль о единении.

Русские в Прибалтике не сумели переделать инфраструктуру общества. Все попытки гарнизонов создать «свой мирок», перенести для себя в незнакомый мир «свою Русь» оказались непрочными. Империя должна вкладывать в новоосваиваемый мир довольно значительные ресурсы, но особого притока ресурсов из России в Ливонию не происходило. Гарнизоны ливонских крепостей испытывали существенные трудности. [Angermann, S. 25-64; Filiushkin, 2013]. Особую проблему составляла малочисленность православных церквей. Не хватало священников, храмов, их было непросто построить [Селин]. Люди умирали без отпевания и исповеди, что страшило особо: «Милостивый государь, смилуйся, пощади нас, холопов твоих, вели изо Пскова прислать попа, умирают, государь, твои государские люди без отца духовного, а мы, холопы твои государские, живем что овцы, заблудившиеся без пастуха» (1578 г., между 17 и 21 января. Отписка круцборгского воеводы кн. М. М. Путятина в Городовой приказ) [Памятники истории Восточной Европы, с. 61]).

Москва попыталась решить вопрос на политическом уровне: применить в Прибалтике модель Священной Римской империи, учредить собственное королевство, вручить власть над вассальным государством из рук русского царя так же, как вручал европейские короны германский император. Речь идет о знаменитом проекте «королевства Магнуса». Его идея, как известно, была разработана именно немецкими политиками и изначально развивалась в рамках германской политической культуры. Россия мыслилась как субъект, который восстановит под своей властью территориальную целостность Ливонии (а лучше - Ливонии и Пруссии, т. е. возродит Тевтонский орден), а затем передаст ее правителям ордена на условии выплаты дани, т. е. признания сюзеренитета московского государя. По сведениям папского нунция в Польше Джованни Франческо Коммендоне, царь выдвигал следующие условия: «Правитель вассального Ливонского государства возвратит русским православные церкви в Ливонии со всеми их доходами; все главные крепости Ливонии останутся в руках московитов; в совете магистра должны заседать шесть московитов с решающим голосом; правитель Ливонии может выступать в военные походы только с согласия царя; переход власти (после смерти правителя) происходит по усмотрению Москвы: русский царь назначает следующего владыку в Ливонию». Как справедливо отметил Анти Селарт, получалось, что русский царь должен был 
взять на себя в отношении Ливонии роль императора, который признает автономность своего вассала ${ }^{3}$.

В 1564 г. проект не был реализован из-за того, что желающих на роль вассала не нашлось. Лишь в 1569-1570 гг. датский герцог Магнус принял предложение Ивана IV и, как считается, основал Ливонское королевство практически на тех же условиях, что обсуждались пятью годами ранее [Zel̦enkovs; Leimus; Olesen]. А. Адамсон, видимо, справедливо видит одной из причин реанимации проекта Ливонского королевства в конце 1560-х гг. некий политический тупик, в который зашла ситуация в Ливонии (собственно политические амбиции датских Ольденбургов - это другая сторона медали [Adamson, 1. 9-11, 232-233]). Военным путем она не решалась, завоевать всю Ливонию ни одной из сторон (полякам, литовцам, шведам, датчанам, русским) не удалось. Раздел по принципу «Кто чем владеет» не получался, - собственно, только Россия и Дания в 1562-1563 гг. заключили международное соглашение, в котором признали захваты сторон в Ливонии (причем Дания признала даже будущие захваты России, еще не случившиеся). Между всеми остальными участниками аннексии Ливонии согласия не было. К тому же, как замечает А. Адамсон, надо было еще добиться признания легитимности захватов от Священной Римской империи, поскольку Ливония являлась бывшей имперской провинцией. Вариант с созданием в Ливонии вассального королевства здесь подходил идеально. Европейские монархии получали шанс участвовать в судьбах Ливонии через решение династической проблемы [Ibid., 1. 25, 75]. Это была модель, понятная политической культуре германской империи.

Правда, это дало неожиданный для Москвы эффект: королевство Магнуса в Ливонии воспринималось местными жителями не как вассальная провинция Московии, но скорее как некое послабление оккупационного режима, передача его под управление братьев по вере датских протестантов, т. е. с Магнусом в Ливонию частично вернулась Европа. И хотя наемные войска датского принца воевали вместе с русскими детьми боярскими против шведов и поляков, местное население относилось к ним куда менее враждебно, чем к российским войскам. Тем самым Королевство Магнуса работало не на превращение Ливонии в провинцию Российской империи (по аналогии со Священной Римской империей), но, напротив, подрывало саму имперскую идею на корню. Не говоря уже о том, что зависимость «ливонского короля» от «русского кайзера» получалась чисто личной, никаких социально-политических и социально-экономических структурных преобразований по интеграции Ливонии в Московию Магнус не проводил и не собирался этого делать [Renner, 1988]. В результате усилилось «срединное состояние» Ливонии (можно говорить о маргинализации политических процессов в Ливонии при Магнусе

\footnotetext{
${ }^{3}$ Подробнее об этих планах и их развитии см.: [Селарт, 2013]; письмо Коммедоне: Commedone. Al medesimo a li 19. Decembre 1564 di Petrikovia [Акты исторические..., c. 203].
} 
[Hübner]). Благодаря Магнусу вектор ее превращения в русский уезд с центром в Юрьеве Ливонском перестал быть столь уж предопределенным.

Уход России из Ливонии по результатам Ям-Запольского перемирия 1582 г. (кстати, это первый в истории случай массовой эвакуации русских войск и населения с занятых территорий) поставил точку в проекте «Русской Ливонии», хотя титул «Ливонский» продолжал носить царь Федор Иванович (1584-1598). Это показывает, что Россия считала спор о Прибалтике незаконченным. Борьба за Ливонию в 1558-1583 гг. стала своего рода срединным - дипломатическим и военным - проектом русской истории.

Планы возвращения в Прибалтику правительством Федора Ивановича были реализованы вполне успешно. После русско-шведской войны 1589-1590 гг. и Тявзинского мира 1595 г. Россия вернула почти все территориальные потери, понесенные от шведов (кроме Нарвы) и фактически вернулась к довоенным границам 1558 г. Но Русская Смута гражданская война начала XVII в. - надолго отбросила назад геополитические планы Москвы и лишила ее балтийских берегов, превратив после Столбовского мира 1618 г. Балтийское море в «шведское озеро».

Опыт Русской Прибалтики был в дальнейшем не востребован для русского имперского строительства. Им интересовались, но не более того. Он не стал руководством к действию. В XVII в. Посольский приказ заказывал копии Жалованной грамоты Дерпту 1564 г. [Курукин, с. 36] и переводы международных договоров, связанных с Ливонской войной. Был составлен специальный сборник посольских грамот последнего периода войны [Филюшкин, 2002]. Но прибалтийские завоевания царя Алексея Михайловича (Дерпт и Вильно) в конце концов пришлось возвращать.

Такой же всплеск интереса к документации, связанной с борьбой за Прибалтику при Иване Грозном, будет происходить в начале XVIII в., когда аналогичные копии и переводы будут делаться по приказу Петра I ${ }^{4}$. Но Петр Алексеевич строил свою империю на иных началах, и, как показала история, более долговечно. После успеха русского имперского проекта в начале XVIII в. проекту «Русской Ливонии» был окончательно присвоен статус неудачного исторического опыта, всего лишь предшествующего великим победам первого российского императора и оттеняющего их славу и величие.

4 Перевод с договора между королем Сигизмундом и последним магистром Готардом Кетлером о отдаче в польскую сторону Лифляндии. 28 ноября 1561 г. Копия начала XVIII в. [РГАДА, ф. 64, оп. 1, д. 4]; Список на латинском языке и перевод ратификации польского короля Жигимонта Августа на учиненный между им, королем, и между Готурдом, лифляндским магистром кавалерии ордена Теитонического против России, 28 ноября 1561 года. Рукопись 1723 г. [Там же, д. 5]. 
Акты исторические, относящиеся до России, извлеченные из иностранных архивов и библиотек А. И. Тургеневым. СПб. : Тип. Эдуарда Праца, 1841. Т. I. 434 с.

Алексеев Л. В. Полоцкая земля (очерки истории Северной Белоруссии). М. : Наука, 1966. 295 с.

Бессуднова М. Б. История Великого Новгорода конца XV - начала XVI в. по ливонским источникам. Великий Новгород : Новгород. гос. ун-т, 2009a. 244 с.

Бессуднова М. Б. Петрову двору капут: закрытие ганзейской конторы в Новгороде// Родина. 2009б. № 9. С. 43-46.

Бессуднова М. Б. Превратность судьбы (Великий Новгород в системе руссколивонских отношений) // Новгородский исторический сборник. 2013. Вып. 13 (23). C. $171-184$.

Бессуднова М. Б. «Русская угроза» в свете ливонской орденской документации 80-90-х годов XV в. // Studia Slavica et Balcanica Petropolitana. 2014. № 1. С. 26-37.

Казакова Н. А. Ганзейская политика русского правительства в последние годы XV в. (русско-ганзейские переговоры 1498 г.) // Проблемы общественно-политической истории России и славянских стран : сб. ст. к 70-летию академика М. Н. Тихомирова. М. : Изд-во вост. лит., 1963. С. 150-157.

Казакова Н. А. Русско-ливонские и русско-ганзейские отношения. Конец XIV начало XVI в. Л. : Наука, 1975. 358 с.

Коваленко Г., Смирнов В. Легенды и загадки Земли Новгородской. М. : Вече, 2007. 372 с.

Косточкин B. В. Русские военно-оборонительные сооружения XVI в. у устья Наровы // Краткие сообщения Института истории материальной культуры. 1953. Вып. 52. С. 25-32.

Курукин И. В. К изучению источников о начале Ливонской войны и деятельности правительства Адашева и Сильвестра // Источниковедческие исследования по истории феодальной России. М. : Ин-т ист. СССР, 1981. С. 29-38.

Маазинг М. «Русская опасность» в письмах Рижского архиепископа Вильгельма за 1530-1550-е гг. // Studia Slavica et Balcanica Petropolitana. 2010. № 1. C. 184-192.

Назарова Е. Л. Из истории взаимоотношений ливов с Русью (X-XIIIвв.) // Древнейшие государства на территории СССР. М. : Наука, 1986. С. 177-183.

Назарова Е. Л. Русско-латгальские контакты в XII-XIII вв. в свете генеалогии князей Ерсики и Кокнесе // Древнейшие государства на территории СССР. 1992-1993 гг. М. : Наука, 1995. С. 182-196.

Ниенштедт Ф. Ливонская хроника // Сборник материалов и статей, относящихся к истории Прибалтийского края. Рига: Тип. А. И. Липинского, 1883. С. 7-124.

Новиикий $\Gamma$. А. Новые данные о русском феодальном землевладении в Прибалтике в период Ливонской войны (1558-1582) // Вопросы истории. 1956. № 4. C. $132-138$.

Носов К. С. Русские крепости конца XV-XVII вв. СПб. : Нестор-История, 2009. 248 с.

Опарина T. A. Род Фаренсбахов во второй половине XVI в. // Человек в пространстве и времени культуры. Барнаул : Алт. гос. ун-т, 2008. С. 40-86.

Памятники истории Восточной Европы. Источники XV-XVII вв. Т. 3 : Документы Ливонской войны (подлинное делопроизводство приказов и воевод). 1571-1580 гг. М. ; Варшава : Археограф. центр, 1998. 288 с.

Пиотух Н. В. Служилые люди на Ливонской войне // Археология и история Пскова и Псковской земли : материалы науч. семинаров за 2001-2002 гг. Псков : Ин-т археологии РАН : Псков. гос. объединенный историко-архитектурный и художественный музей-заповедник, 2003. С. 161-183.

Полное собрание русских летописей (ПСРЛ). Т. 2. М., 1998.

РГАДА. Ф. 64 (Сношения с Лифляндией). Оп. 1. Д. 4-5.

Селарт A. «Русские бояре» в Эстляндии (конец XVI - начало XVII вв.) // Studia Slavica et Balcanica Petropolitana. 2012. № 2. C. 3-14.

Cеларт A. Иван Грозный, Кайзер Ливонский? К истории возникновения идеи о российском вассальном государстве в Ливонии // Studia Slavica et Balcanica Petropolitana. 2013. № 2. C. 180-197.

Селарт A. Тайна купцов, забота дипломатов: русский язык в средневековой Ливонии // Лотмановский сборник 4. М. : ОГИ, 2014. С 48-60.

Селин A. A. Московское церковное строительство в Ливонии в XVI в. // Археология и история Пскова и Псковской земли : материалы науч. семинара за 2000 г. Псков : Ин-т археологии РАН : Псков. гос. объединенный историко-архитектурный и художественный музей-заповедник, 2001. С. 242-247. 
Скобелкин $О$. В. Ливонская война и западноевропейцы в русском войске // Балтийский вопрос в конце XV-XVI вв. М. : Квадрига, 2010. С. 207-220.

Филюшкин А. И. Дискурсы Ливонской войны // Аb Imperio. 2001. № 4. С. 43-80.

Филюшкин А. И. Сборник с посольскими посланиями Ивана Грозного в Речь Посполитую // Историческое источниковедение и проблемы вспомогательных исторических дисциплин. К 140-летию академика Николая Петровича Лихачева (1862-1936) и 100-летию Дома Н. П. Лихачева в Санкт-Петербурге : тез. докл. конф. Санкт-Петербург, 3-5 декабря 2002. СПб. : Петерб. ин-т истории, 2002. С. 86-88.

Филюшкин А. И. Проблема генезиса Российской империи // Новая имперская история постсоветского пространства. Казань : Центр исследований национализма и империи, 2004. С. 375-408.

Филюшкин А. И. Политическая практика московских властей в Ливонии в период Ливонской войны (новые документы) // Studia Slavica et Balcanica Petropolitana. 2008. № 1. C. $78-83$.

Флоря Б. Н. К истории русского поместного землевладения в Ливонии // Русский дипломатарий. М., 1999. Вып. 5. С. 114-117.

Adamson A. Liivimaa kuningriik. Tallinn : Argo, 2013. $248 \mathrm{lk}$. $134 \mathrm{~S}$.

Angermann N. Studien zur Livlandpolitik Ivan Groznyjs. Marburg : Lann, 1972.

Attman A. The Russian and Polish Markets in International trade: 1500-1650. Göteborg : Institute of Economic History of Gothenburg University, 1973. 232 p.

Filiushkin A. Der Diskurs von der Notwendigkeit des Durchbruchs zur Ostsee in der russischen Geschichte und Historiographie // Narva und die Ostseeregion. Narva : TU Narva Kolledz, 2004. S. 171-184.

Filiushkin A. The Livonian War and the Mentality of the Russian Nobles // CanadianAmerican Slavic Studies. 2013. Vol. 47. P. 420-435.

Forstreuter K. Preussen und Russland von den Anfängen des Deutschen Ordens bis zu Piter dem Grossen. Göttingen : Musterschmidt, 1955. 257 S.

Hübner E. Zwischen allen Fronten. Magnus von Holstein als König von Livland // Zwischen Christianisierung und Europäisierung. Beiträge zur Geschichte Osteuropas in Mittelalter und früher Neuzeit. Stuttgart, 1998 (Quellen und Studien zur Geschichte des östlichen Europa. Bd. 51). S. 313-333.

Kampfer F. Die Eroberung von Kazan 1552 als Gegenstand der zeitgenossischen rusischen historiographie // Forschungen zur osteuropaischen Geschichte. 1969. Bd. 14. S. 7-161. Keenan E. Muscovy and Kazan: Some introdactory remarks on the Patterns of Steppe Diplomacy // Slavic Review. 1967. Vol. 26. P. 548-558.

Kirchner $W$. The rise of the Baltic question. Westport : Greenwood Press, 1970. 283 p. Leimus I. Hertsog Magnus, tema võlad ja võlausaldajad // Tuna. 2008. T. 11 Bd 2 (38).

Lk. 8-18.

Martin J. Two Pomeshchiki from the Novgorod Lands: Their Fates and Fortunes during the Livonian War // Russian History. 2007. Vol. 34. P. 239-253.

Olesen J. Die Hochstifte Ösel und Kurland unter dänischen Herrschaft // Die baltischen Lande im Zeitalter der Reformation und Konfessionalisierung. Livland, Estland, Ösel, Ingermanland und Lettgallen. Stadt, Land und Konfession 1500-1721. T. 2. Münster, 2010 (Katholisches Leben und Kirchenreform im Zeitalter der Glaubensspaltung. Bd. 70). S. 191-216. Pelensky J. Muscovite imperial Claims to the Kazan Khanate // Slavic Review. 1967. Vol. 26. P. 559-576.

Pelensky J. Russia and Kazan. Conquest and Imperial Ideology (1438-1560s). Hague : Mouton, 1974. $368 \mathrm{p}$.

Pritsak $O$. Moscow, the Golden Horde and the Kazan khanate from a Polycultural point of View // Slavic Review. 1967. Vol. 26. P. 577-583.

Renner J. Livländische Historien 1556-1561. Lübeck : Schmidt-Römhild, 1953. 150 S.

Renner U. Herzog Magnus von Holstein als Vasall des Zaren Ivan Groznyj // Deutsch-

land - Livland - Rußland. Ihre Beziehungen vom 15. bis zum 17. Jahrhundert. Beiträge aus dem Historischen Seminar der Universität Hamburg. Lüneburg : Nordostdeutsches Kulturwerk, 1988. S. 137-158.

Schirren $C$. Neue Quellen zur Geschichte des Untergangs livländischer Selbständigkeit.

Reval : F. Kluge, 1883. Bd. 1.389 S.

Selart A. Eesti idapiir keskajal. Tartu : Tartu Ülikooli Kirjastus, 1998. 207 lk.

Selart A. Pärnu Liivi sõja aegse Vene halduskeskusena // Pärnumaa ajalugu. 2002. Kd. 5. Lk. 21-33. 
Selart A. Livland und die Rus'im 13. Jahrhundert. Köln ; Weimar ; Wien : Böhlau, 2007. $373 \mathrm{~S}$

Selart A. The Orthodox Monastery in Tartu during the Livonian War // Tuna. Ajalookultuuri ajakiri. Past. Special Issue on the history of Estonia. 2009. P. 46-55.

Starodubec P. A. Das russische Fürstentum Kukenois im Ostbaltikum zu Beginn des 13.

Jahrhunderts // Jahrbuch für Geschichte der UdSSR und der volksdemokratischen Länder Europas. 1959. Bd. 3. S. 342-364.

Taube M. Russische und litauische Fürsten an der Düna zur Zeit der deutschen Eroberung Livlands (XII. und XIII. Jahrhundert) // Jahrbücher für Kultur und Geschichte der Slaven. 1935. Bd 11. S. 367-502.

Tiberg E. Die politik Moskaus gegenüber Alt-Livland: 1550-1558 // Zeitschrift für Ostforschung. 1976. T. 25. S. 577-617.

Tvauri A. Muinas-Tartu. Uurimus Tartu muinaslinnuse ja asula asustusloost. Tartu ; Tallinn : Tartu Ülikool, 2001. $371 \mathrm{lk}$.

Zeļenkovs A. Dānijas prinča Magnusa (1540-1583) darbība Livonijā // Latvijas Kara muzeja gadagrāmata. Rīga : Latvijas Kara muzejs, 2000. Lp. 15-30.

Adamson, A. (2013). Liivimaa kuningriik. Tallinn: Argo.

Akty' istoricheskie, otnosyashhiesya do Rossii, izvlechenny'e iz inostranny'h arhivov $i$ bibliotek A. I. Turgenevy' $m$ [Historical acts, referred to before Russia, taken from foreign archives and libraries by A. I. Turgenev]. (1841). (Vol. 1). St. Petersburg: Tip. E'duarda Pracza.

Alekseev, L. V. (1966). Poloczkaya zemlya (ocherki po istorii Severnoj Belorussii) [Polotskian land (essays on the history of Northern Belorussia)]. Moscow: Nauka.

Angermann, N. (1972). Studien zur Livlandpolitik Ivan Groznyjs. Marburg: Lann.

Attman, A. (1973). The Russian and Polish Markets in International trade: 1500-1650. Göteborg : Institute of Economic History of Gothenburg University.

Bessudnova, M. B. (2009). Istoriya Velokogo Novgoroda koncza XV-nachala XVI v. po livonskim istochnikam [The history of Velikiy Novgorod in the late $15^{\text {th }}-$ early $16^{\text {th }} \mathrm{c}$. by Livonian sources]. Velikij Novgorod: Novgorod. gos. un-t.

Bessudnova. M. B. (2009). Petrovu dvoru kaput: zakry'tie ganzejskoj kontory' v Novgorode [The end of Peter the Great's court: closing of Hanseatic office in Novgorod]. Rodina [Motherland], 9, 43-46.

Bessudnova, M. B. (2013). Prevratnost' sud'by' (Velikij Novgorod v sisteme russkolivonskih otnoshenij) [Adversity (Velikiy Novgorod in the system of Russian-Livonian relations)]. In Novgorodskij istoricheskij sbornik [Novgord historical composite book]. (Iss. 13 (23)) (p. 171-184).

Bessudnova, M. B. (2014). "Russkaya ugroza" v svete livonskoj ordenskoj dokumentacii 80-90-h godov XV v. ["Russian threat" in the light of Livonian Order documents of 80-90s years of 15 c.]. Studia Slavica et Balcanica Petropolitana, 1, 26-37.

Filiushkin, A. I. (2001). Diskursy' Livonskoj vojny' [Discourse of the Livonian war]. Ab Imperio, 4, 43-80.

Filiushkin, A. I. (2002). Sbornik s posol'skimi poslaniyami Ivana Groznogo v Rech' Pospolituyu [Collection of Polish letters of Ivan the Great to the Polish-Lithuanian Commonwealth]. In Istoricheskoe istochnikovedenie i problemy' vspomogatel'ny'h istoricheskih disciplin. K 140-letiyu akademika Nikolaya Petrovicha Lihacheva (1862-1936) i 100-letiyu Doma N. P. Lihacheva v Sankt-Peterburge: tez. dokl konf. Sankt-Peterburg, 3-5 dekabrya. [Historical source study and the problems of supportive historical disciplines. To the $140^{\text {th }}$ anniversary of the birth of academician N. P. Lihachev (1862-1936) and $100^{\text {th }}$ anniversary of N. P. Lihachev's house in St. Peterburg: abstracts of the conference. St. Petersburg, 3-5 December] (p. 86-88). St. Peterburg: Peterb. in-t istorii.

Filiushkin, A. (2004). Der Diskurs von der Notwendigkeit des Durchbruchs zur Ostsee in der russischen Geschichte und Historiographie. In Narva und die Ostseeregion (p. 171-184). Narva: TU Narva Kolledz.

Filiushkin, A. I. (2004). Problema genezisa Rossijskoj imperii [The problem of the genesis of the Russian Empire]. In Novaya imperskaya istoriya postsovetskogo prostranstva [The new imperial history of the former Soviet Union] (p. 375-408). Kazan: Centr issledovanij nacionalizma i imperii. 
Filiushkin, A. I. (2008). Politicheskaya praktika moskovskih vlastej v Livonii v period Livonskoj vojny' (novy'e dokumenty') [Political practice of Moscow authorities in Livonia during the Livonian war (new documents)]. Studia Slavica et Balcanica Petropolitana, 1, 78-83.

Filiushkin, A. (2013). The Livonian War and the Mentality of the Russian Nobles. Canadian-American Slavic Studies, 47, 420-435.

Florya, B. N. (1999). K istorii russkogo pomestnogo zemlevladeniya v Livonii [To the history of Russian manorial landowing in Livonia]. In Russkij diplomatarij [Russian diplomatary]. (Iss. 5) (p. 114-117). Moscow.

Forstreuter, K. (1955). Preussen und Russland von den Anfängen des Deutschen Ordens bis zu Piter dem Grossen. Göttingen: Musterschmidt.

Hübner, E. (1998). Zwischen allen Fronten. Magnus von Holstein als König von Livland. In Zwischen Christianisierung und Europäisierung. Beiträge zur Geschichte Osteuropas in Mittelalter und früher Neuzeit. (Quellen und Studien zur Geschichte des östlichen Europa. Bd. 51) (p. 313-333). Stuttgart.

Kampfer, F. (1969). Die Eroberung von Kazan 1552 als Gegenstand der zeitgenossischen rusischen historiographie. Forschungen zur osteuropaischen Geschichte, 14, 7-161.

Kazakova, N. A. (1963). Ganzejskaya politika russkogo pravitel'stva v poslednie gody' XV v. (russko-ganzejskie peregovory' 1498 g.) [Hanseatic policy of Russian government in the last years of XV c. (Russian-Livonian negotiations of 1498 yr.)]. In Problemy' obshhestvenno-politicheskoj istorii Rossii i slavyanskih stran: sb. st. $k$ 70-letiyu akademika M. N. Tihomirova [The problems of sociopolitical history of Russia and Slavic countries: collection of articles to the $70^{\text {th }}$ anniversary of academician M. N. Tikhomirov] (p. 150157).Moscow: Izd-vo vost. lit.

Kazakova, N. A. (1975). Russko-livonskie i russko-ganzejskie otnosheniya. Konecz $X I V$-nachalo XVI v. [Russian-Livonian and Russian-Hanseatic relations. Late $14^{\text {th }}-$ early $16^{\text {th }}$ c.]. Leningrad: Nauka.

Keenan, E. (1967). Muscovy and Kazan: Some introdactory remarks on the Patterns of Steppe Diplomacy. Slavic Review, 26, 548-558.

Kirchner, W. (1970). The rise of the Baltic question. Westport: Greenwood Press.

Kostochkin, V. V. (1953). Russkie voenno-oboronitel'ny'e sooruzheniya XVI v. u ust'ya Narovy' [Russian military defensive fortification of $16^{\text {th }} \mathrm{c}$. at Narva creek]. In Kratkie soobshheniya Instituta istorii material'noj kul'tury' [Brief reports of the Institute of history of material culture]. (Vol. 52) (p. 25-32).

Kovalenko, G. \& Smirnov, V. (2007). Legendy' i zagadki Zemli Novgorodskoj [Legends and riddles of Novgorod land]. Moscow: Veche.

Kurukin, I. V. (1981). K izucheniyu istochnikov o nachale Livonskoj vojny' i deyatel'nosti pravitel'stva Adasheva i Sil'vestra [Studying of sources on the beginning of the Livonian was and activity of the government of Adashev and Sylvester]. In Istochnikovedcheskie issledovaniya po istoriifeodal'noj Rossii [Source studies researches on the history of feudal Russia] (p. 29-38). Moscow: In-t ist. SSSR.

Leimus, I. (2008). Hertsog Magnus, tema võlad ja võlausaldajad. Tuna, 2 (38), 8-18.

Martin, J. (2007). Two Pomeshchiki from the Novgorod Lands: Their Fates and Fortunes during the Livonian War. Russian History, 34, 239-253.

Maazing, M. (2010). "Russkaya opasnost"” v pis'mah Rizhskogo arhiepiskopa Vil'gel'ma za 1530-1550-e gg. ["Russian danger" in the letters of Vilgelm archbishop of Riga for the 1530-1550s yrs.]. Studia Slavica et Balcanica Petropolitana, 1, 184-192.

Nazarova, E. L. (1986). Iz istorii vzaimootnoshenij livov s Rus'yu (X-XIII vv.). [From the history of relations of Livs with Russia $\left(10^{\text {th }}-13^{\text {th }}\right.$ cc. $\left.)\right]$. In Drevnejshie gosudarstva na territorii SSSR [The most ancient nations on the territory of the USSR] (p. 177-183). Moscow: Nauka.

Nazarova, E. L. (1995). Russko-latgal'skie kontakty' v XII-XIII vv. v svete genealogii knyazej Ersiki i Koknese [Russian-Latgalian contacts in $12^{\text {th }}-13^{\text {th }} \mathrm{cc}$. in the light of genealogy of the princes of Ersika and Koknese]. In Drevnejshie gosudarstva na territorii SSSR. 1992-1993 gg. [The most ancient nations on the territory of the USSR. 1992-1993 yrs.] (p. 182-196). Moscow: Nauka.

Neinshtedt, F. (1883). Livonskaya hronika [Livonian chronicle]. In Sbornik materialov $i$ statej, otnosyashhihsya k istorii Pribaltijskogo kraya [Collection of materials and articles referred to the history of the Baltic region] (p. 7-124). Riga: Tip. A. I. Lipinskogo. 
Nosov, K. S. (2009). Russkie kreposti koncza XV-XVII vv. [Russian fortresses of the late $15^{\text {th }}-17^{\text {th }}$ cc.]. St. Petersburg: Nestor-Istoriya.

Noviczkij, G. A. (1965). Novy'e danny'e o russkom feodal'nom zemlevladenii v Pribaltike v period Livonskoj vojny' (1558-1582) [New information on Russian feudal tenure in the Baltics during the Livonian war (1558-1582)]. Voprosy' istorii [Historical issues], 4, $132-138$.

Olesen, J. (2010). Die Hochstifte Ösel und Kurland unter dänischen Herrschaft. In Die baltischen Lande im Zeitalter der Reformation und Konfessionalisierung. Livland, Estland, Ösel, Ingermanland und Lettgallen. Stadt, Land und Konfession 1500-1721. T. 2. Münster (Katholisches Leben und Kirchenreform im Zeitalter der Glaubensspaltung. Bd. 70) (p. 191-216).

Oparina, T. A. (2008). Rod Farensbahov vo vtoroj polovine XVI v. [The family of Farensbah in the second half of $16^{\text {th }} \mathrm{c}$.]. In Chelovek $v$ prostranstve $i$ vremeni kul'tury ${ }^{\prime}$ [A man in the space and time of culture] (p. 40-86). Barnaul: Alt. gos. un-t.

Pamyatniki istorii Vostochnoj Evropy'. Istochniki XV-XVII vv. T. 3: documenty' Livonskoj vojny' (podlinnoe deloproizvodstvo prikazov $i$ voevod). 1571-1580 gg. [Historical monuments of the Western Europe. The sources of $15^{\text {th }}-17^{\text {th }} \mathrm{cc}$. Documents of the Livonian war (original paperwork management on orders and voevodes). 1571-1580 yrs.]. (1998). Moscow; Warsaw: Arheograficheskij centr.

Pelensky, J. (1967). Muscovite imperial Claims to the Kazan Khanate. Slavic Review, 26, 559-576.

Pelensky, J. (1974). Russia and Kazan. Conquest and Imperial Ideology (1438-1560s). Hague: Mouton.

Piotuh, N. V. (2003). Sluzhily'e lyudi na Livonskoj vojne [Noblemen at the Livonian war]. In Arheologiya i istoriya Pskova i Pskovskoj zemli: materialy' nauchny'h seminarov za 2001-2002 gg. [Archaeology and history of Pskov and Pskov region: materials of scientific workshops for the period of 2001-2002 yrs.] (p. 161-183). Pskov: In-t arheologii RAN; Pskov. gos. ob"edinenny'j istoriko-arhitekturny'j i hudozhestvenny'j muzej-zapovednik.

Pritsak, O. (1967). Moscow, the Golden Horde and the Kazan khanate from a Polycultural point of View. Slavic Review, 26, 577-583.

Renner, J. (1953). Livländische Historien 1556-1561. Lübeck: Schmidt-Römhild.

Renner, U. (1988). Herzog Magnus von Holstein als Vasall des Zaren Ivan Groznyj. In Deutschland - Livland - Rußland. Ihre Beziehungen vom 15. bis zum 17. Jahrhundert. Beiträge aus dem Historischen Seminar der Universität Hamburg (p. 137-158). Lüneburg: Nordostdeutsches Kulturwerk.

Schirren, C. (1883). Neue Quellen zur Geschichte des Untergangs livländischer Selbständigkeit. Reval: F. Kluge.

Selart, A. (1998). Eesti idapiir keskajal. Tartu: Tartu Ülikooli Kirjastus.

Selart, A. (2002). Pärnu Liivi sõja aegse Vene halduskeskusena. Pärnumaa ajalugu, 5, 21-33.

Selart, A. (2007). Livland und die Rus' im 13. Jahrhundert. Köln; Weimar; Wien: Böhlau.

Selart, A. (2009). The Orthodox Monastery in Tartu during the Livonian War. In Tuna. Ajalookultuuri ajakiri. Past. Special Issue on the history of Estonia (p. 46-55).

Selart, A. (2012). "Russkie boyare" v E'stlyandii (konecz XVI - nachalo XVII vV.) ["Russian boyars" in Estonia (late $16^{\text {th }}-$ early $17^{\text {th }}$ cc.]. Studia Slavica et Balcanica Petropolitana, 2, 3-14.

Selart, A. (2013). Ivan Grozny'j, Kaizer Livonskij? K istorii vozniknoveniya idei o rossijskom vassal'nom gosudarstve v Livonii [Ivan the Great, Ceasar Livonian? To the history of the idea of Russian vassal state in Livonia]. Studia Slavica et Balcanica Petropolitana, 2, 180-197.

Selart, A. (2014). Tajna kupczov, zabota diplomatov: russkij yazy'k v slednevekovoj Livonii [Merchants' secret, diplomats' concern: the Russian language in the medieval Livonia]. In Lotmanovskij sbornik 4 [Lotmanovsky collection 4] (p. 48-60). Moscow: OGI.

Selin, A. A. (2001). Moskovskoe cerkovnoe stroitel'stvo v Livonii v XVI v. [Moscow church building in Livonia in $16^{\text {th }} \mathrm{c}$.]. In Arheologiya i istoriya Pskova i Pskovskoj zemli: materialy' nauchnogo seminara za $2000 \mathrm{~g}$. [Archaeology and history of Pskov and Pskov region: materials of scientific workshop for 2000 yr.] (p. 242-247). Pskov: In-t arheologii RAN; Pskov. gos. ob"edinenny'j istoriko-arhitekturny'j i hudozhestvenny'j muzejzapovednik. 
Skobelkin, O. V. (2010). Livonskaya vojna i zapadnoevropejcy' v russkom vojske [The Livonian war and west-europeans in Russian army]. In Baltijskij vopros v konce XV-XVI vv. [Baltic question in the end of $15^{\text {th }}-16^{\text {th }}$ cc.] (p. 207-220). Moscow: Kvadriga.

Starodubec, P. A. (1959). Das russische Fürstentum Kukenois im Ostbaltikum zu Beginn des 13. Jahrhunderts. Jahrbuch für Geschichte der UdSSR und der volksdemokratischen Länder Europas, 3, 342-364.

Taube, M. (1935). Russische und litauische Fürsten an der Düna zur Zeit der deutschen Eroberung Livlands (XII. und XIII. Jahrhundert). Jahrbücher für Kultur und Geschichte der Slaven, 11, 367-502.

Tiberg, E. (1976). Die politik Moskaus gegenüber Alt-Livland: 1550-1558. Zeitschrift für Ostforschung, 25, 577-617.

Tvauri, A. (2001). Muinas-Tartu. Uurimus Tartu muinaslinnuse ja asula asustusloost. Tartu; Tallinn: Tartu Ülikool.

Zel̦enkovs, A. (2000). Dānijas prinča Magnusa (1540-1583) darbība Livonijā. In Latvijas Kara muzeja gadagrāmata (p. 15-30). Rīga: Latvijas Kara muzejs.

The article was submitted on 21.05.2014

\author{
Александр Ильич Филюшкин \\ профессор \\ Россия, Санкт-Петербургский \\ государственный университет \\ a.filushkin@spbu.ru
}

\author{
Alexander Filiushkin \\ Professor \\ Russia, Saint Petersburg \\ State University \\ a.filushkin@spbu.ru
}

